\title{
Kelet-Közép-Európa területi folyamatai, 1990-2015. Beszámoló a Magyar Regionális Tudományi Társaság XIII. vándorgyüléséről
}

\author{
Regional Processes of Central and Eastern Europe, \\ 1990-2015. Report on the 13th Annual Meeting of the \\ Hungarian Regional Science Association
}

\author{
KOVÁCS SÁNDOR ZSOLT, RÁCZ SZILÁRD
}

\begin{abstract}
KOVÁCS Sándor Zsolt: tudományos segédmunkatárs, MTA Közgazdaság- és Regionális Tudományi Kutatóközpont, Regionális Kutatások Intézete, Pécs; skovacs@rkk.hu RÁcZ Szilárd: tudományos titkár, MTA Közgazdaság- és Regionális Tudományi Kutatóközpont, Regionális Kutatások Intézete, Pécs; szracz@rkk.hu
\end{abstract}

Sándor Zsolt KOVÁCS: junior research fellow, Institute for Regional Studies, Centre for Economic and Regional Studies, Hungarian Academy of Sciences, Pécs; skovacs@rkk.hu

Szilárd RÁCZ: scientific secretary, Institute for Regional Studies, Centre for Economic and Regional Studies, Hungarian Academy of Sciences, Pécs; szracz@rkk.hu

A Magyar Regionális Tudományi Társaság XIII. vándorgyülésének az egri Eszterházy Károly Főiskola adott helyet 2015. november 19-én és 20-án. A kétnapos tanácskozás a rendszerváltozástól napjainkig végbemenő területi folyamatokat kívánta megvitatni a közép- és kelet-európai térségre koncentrálva. $\mathrm{E}$ célkitűzés megvalósításához mintegy 190 résztvevő és közel 100 magyar, valamint 12 angol nyelvủ előadás járult hozzá. A konferencia - a korábbi gyakorlatnak megfelelően - a társaság közgyűlésével kezdődött, amelynek legfontosabb napirendi pontjai az alapító okirat módosítása, valamint a tisztújítás volt. Az alapító okirat módosítására jogszabályi változások következtében került sor. A 2011-ben megválasztott tisztségviselők négyéves mandátumának lejártával a közgyűlés szavazott a társaság új tisztségviselőiről. A 284 tagból 55 fó vett részt a szavazáson. Újraválasztását követően a társaság elnöke Rechnitzer János, titkára Rácz Szilárd maradt. Az új alelnökök Lengyel Imre, Nagy Imre és Szabó Pál. Az elnökség tagjai: Fábián Attila, G. Fekete Éva, Gál Zoltán, Józsa Viktória, Káposzta József, Varga Attila és Mezei Katalin (póttag). A Számvizsgáló Bizottság elnöke Tóth Tamás, tagjai Kovács Sándor Zsolt és Kuttor Dániel, póttagja Csáfor Hajnalka lett. A közgyűlés döntése alapján kilenc új és hét újraválasztott

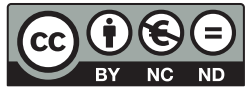


tisztségviselő vesz részt a társaság vezetésében 2015 és 2019 között. A délelőtti program az éves beszámolókkal (elnöki, pénzügyi) és a regionális tagozatok jelentéseivel zárult.

A vándorgyűlés résztvevőit Liptai Kálmán, az Eszterházy Károly Főiskola rektora köszöntötte, majd Rechnitzer János mondta el megnyitóbeszédét. Ezt követően az MRTT elnöke megemlékezett a társaság alapító elnökéről, Horváth Gyula professzorról, aki 2015. szeptember 23-án tragikus hirtelenséggel hunyt el. Ezt követően az angol nyelvű plenáris ülésen mindhárom külföldi előadó megemlékezett Horváth Gyuláról, több évtizedes szakmai és baráti kapcsolatukról.

Az első előadó Daniela L. Constantin, a Román Regionális Tudományi Társaság elnöke, a Bukaresti Közgazdaságtudományi Egyetem professzora volt, aki a Keys to harmonizing EU places through territorial cohesion: A spotlight on services of general interest című előadásában a területi kohézió, a területi tőke és az ún. általános szolgáltatások közötti kapcsolatokat elemezte. Az előadás első felében a területi kohézió és a területi tőke alkalmazott fogalom- és elméletrendszerével ismerkedhetett meg a hallgatóság, majd ezek hatásait mutatta be az előadó az általános szolgáltatások területén. E szolgáltatások között vannak gazdasági (pl. villamosenergia-, gázellátás, postai szolgáltatások, távközlés), illetve szociális (oktatás, egészségügy, bérlakások stb.) jellegűek, közös bennük, hogy az állami hatóságok meghatározó szerepet játszanak e szolgáltatások minőségét, árát és hozzáférhetőségét illetően (megjelennek tehát a területi és társadalmi dimenziók). A SWOT-elemzés kimutatta a területi tőke és kohézió hatásait az általános szolgáltatásokra, a fenntartható, inkluzív gazdasági növekedés lehetőségére, fontos szempont, hogy a nemzeti és regionális célkitüzések összhangja fennmaradjon.

Tomasz Komornicki, a Maria Curie-Skłodowska Egyetem egyetemi tanára, a Lengyel Tudományos Akadémia Földrajzi és Térszervezési Intézetének tudományos igazgatóhelyettese Transport accessibility and the effects of the new investments címmel tartott előadást. A társadalmi fejlődésnek, a gazdasági növekedésnek alapvető feltétele az elérhetőség. Az elérhetőség mérésére használt módszerek (infrastruktúra, távolság, potenciálalapú mérés) közül a potenciálalapú mérés ökonometriai modelljét mutatta be az előadó. Kelet- és Közép-Európában főképp az Európai Unió támogatásainak köszönhetően jelentős változások indultak el, csökkentek a vasúti és közúti elérési idők, javult az összeköttetés a régi és az új uniós tagállamok között, s részben az új tagállamok között is. Azonban hiányosságok is megfigyelhetők, az unió külső határain az összeköttetések mindössze néhány határátkelőre koncentrálódnak, a vasúti beruházások nagy többsége felújítás, új vonalak nem létesültek, a balti államok, valamint Románia és Bulgária vasúthálózata elmaradott az unió többi tagállamához képest. Az előadás második felében a lengyel helyzetet ismerhettük meg részletesebben. Az 1990-es években a lengyel közlekedéspolitika alacsony hatékonysággal müködött, mondhatni, az uniós csatlakozásra várás időszaka volt ez. A csatlakozást követően a 2007-2013-as tervezési periódusban a tervezés nem követte megfelelően a reá- 
lis helyzetet. A 2013-ban megszületett új stratégia azonban már a területi és kohéziós politika céljait is tartalmazta, így az út- és autópálya-fejlesztések pozitív hatással voltak az elérhetőségre, az utazási idő csökkentésére.

James W. Scott, a Kelet-finnországi Egyetem professzora The geopolitics of European Union 25 years on: Transformations and continuity címü elöadásának alapkérdése az volt, hogy milyen politikai közösség, illetve geopolitikai szereplö is valójában az unió. Ennek megítélése igen eltérő mind a politikai, mind pedig a tudományos értekezésekben. A pozitív érvelések szerint az unió egy demilitarizált, multilaterális erőközpont a világban, míg a negatív vélemények szerint a nyugat-kelet megosztottság, a kizsákmányolás és a hatalmi aszimmetriák megtestesítője. A középutat képviselő nézetek szerint az unió szervezete mindössze az állami szervezetek szupranacionális leképezése. A geopolitikai szereplőként való megítélés szintén problematikus; realista, idealista, liberális elemek is megfigyelhetők az Európai Unió, illetve a tagállamok szerepvállalásaiban, megnyilvánulásaiban. A vizsgált 25 évben jelentősen bővült a közösség, így természetes, hogy a területi súlypontok, politikák változáson mentek át, míg az alapértékek jórészt változatlanok maradtak. Az előadás második felében az elöadó kitért több közelmúltbeli, illetve napjainkban is meghatározó eseményre, például a magyar kormány EU-ellenes döntéseire, az ukrán konfliktusra, az EU és Oroszország közötti kapcsolatokra, az EU külső határainak és határpolitikájának változására.

A harmadik angol nyelvű előadáshoz tematikailag kapcsolódva a magyar nyelvü plenáris ülést Hajdú Zoltán, az MTA KRTK Regionális Kutatások Intézetének tudományos tanácsadója nyitotta meg A kettös vasfüggönytől az új kerítések, falak épitéséig címü előadásával. Kiindulópontja a 20. században bekövetkezett európai államföldrajzi átrendeződések, elsősorban a hidegháborút követő változások bemutatása volt. E folyamatok a keleti blokk felbomlásához kötődnek, a szocialista föderációk - a Szovjetunió, Csehszlovákia, Jugoszlávia - szétestek, az új államok születése eltérő módokon ment végbe. Míg Csehszlovákia a két államalkotó nemzet határán bomlott fel, addig Jugoszlávia esetében a soknemzetiségü föderáció soknemzetiségű kis államokra oszlott, véres konfliktusok között, katonai frontok és nemzetközileg kikényszerített határok mentén. A nemzetiségi (kisebbségi) régiók „lázadása” sok esetben a mai napig megfigyelhető az érintett utódállamokban. E folyamatok velejárója volt a korábbi határok és a határvédelmi objektumok (falak, kerítések) egyes részeinek lebontása, megszüntetése, újak létrehozása. A magyar határon lebontották a kettős vasfüggönyt. Az ország előbb a NATO, majd az EU tagjává vált, végül „Schengen” déli, keleti határállama lett, amelynek révén a magyar országhatár nagyobb része uniós külső határként funkcionál (horvát, szerb, román, ukrán határszakaszok). Az előadó kitért az utóbbi években világszerte megfigyelhető kerítés- és falépítési hullámokra, több mint $8000 \mathrm{~km}$ hosszan épültek vagy épülnek határzárak. Európában a balti államok, Bulgária, Ukrajna, Magyarország, valamint Ausztria és Szlovénia esetében figyelhető meg az új határzárak építése. 
G. Fekete Éva, a Miskolci Egyetem Gazdaságtudományi Karának egyetemi tanára a helyi fejlesztések kereteit tekintette át előadásában a szocialista időszaktól egészen napjainkig. A helyi fejlesztési keretek igen szükösek voltak az államszocializmus időszakában, az erős helyi közösségek nemkívánatos elemeknek számítottak. Némi változást 1985-ben a városkörnyéki alap és a települési hozzájárulás hozott. A rendszerváltást követően bár az önkormányzatok megerősödtek, a helyi gazdaságok viszont összeomlottak, a helyi vállalkozói bázis hiányzott, ez is hozzájárult a térségi, kistérségi együttműködésre való törekvéshez. A területfejlesztési politika később (1996-2001) intézményesítette az önkormányzati együttmüködéseket. Önkormányzati fejlesztési társulások, vidékfejlesztési partnerségek jöttek létre, sok esetben az európai uniós források lekötése érdekében. 2001 után az egyre erősödő állami kontroll, a hivatali szemlélet, a társulások egységesítése figyelhető meg a civil szervezetek kirekesztésével párhuzamosan. Az időszak pozitívuma, hogy az uniós csatlakozással a források jelentősen kibővültek. 2011-et követően tovább mélyült az állami központosítás, a társulások felbomlottak, és a szociális szövetkezetek, valamint a közfoglalkoztatás preferálása volt megfigyelhető. Nyilvánvaló, hogy a helyi fejlesztések leginkább a politikától és ezzel összefüggésben a források elérésétől függnek, a jelenlegi szervezeti kereteket csak a LEADER helyi akciócsoportok és a szociális szövetkezetek töltik ki. A kormányzás centralizáltságából kiindulva a további fejlődés (endogén, globalizációs) több szcenáriója körvonalazódik.

Tóth Géza, a Központi Statisztikai Hivatal vezető-tanácsosa Kelet-Közép-Európa térszerkezetének aktuális folyamatai címü előadásában először a szakirodalomban és a fejlesztési tervekben megjelenő térszerkezeti modelleket mutatta be („kék banán”, „napfényövezet”, „közép-európai bumeráng”, „pentagon” stb.), majd kitért a Kelet-Közép-Európát érintő térszerkezeti formákra, ezek relevanciájának elemzésére. A GDP volumenét véve alapul megállapította, hogy a vizsgált térség az európai határok között egységesnek tekinthető, minden régiója a nyugati magterületek felé gravitál, nincs kiemelkedő központja. A gravitációs modell és a Getis-Ord lokális G-statisztikák elemzései azt mutatták, hogy a térségre nem jellemzők az összefüggő tengelyek, nem igazolhatók sem a középeurópai „bumeráng”, sem az „uborka”, sem az „új banán” térszerkezeti formák. A térség gazdasági centrumai a fővárosok, közülük is kiemelkedik némiképp Prága és Pozsony térsége.

Csomós György, a Debreceni Egyetem Műszaki Karának főiskolai tanára A világvárosok uralta tér és a közép-európai eróközpontok pozíciója a gazdaságirányitás globális rendszerében címü előadásában történelmi keretbe helyezte a világvárosok fogalmi kereteit. A Peter Hall-féle koncepció szerint az 1960-as években még hét világvárostérséget említettek, a gazdasági globalizáció mélyülésével új globális és regionális pólusok jelentek meg, melyek egyre jobban részt vesznek a világgazdaság formálásában. Közép-Európa legnagyobb városai a rendszerváltást követően tudták visszaszerezni korábbi jelentőségüket a régió gazdasági életében. A nemzetközi cégcsoportok, szolgáltatási központok megjelenésével 
szintén nőtt a kelet-közép-európai városok szerepe. Az elmúlt évtizedekben Bécs kapuvárosi szerepe csökkent, a régió nyertese egyértelműen Varsó és kismértékben Prága. Budapest pozíciói a kezdeti időszakhoz képest folyamatosan romlanak, azonban több, második és harmadik hierarchiaszinten elhelyezkedő magyar város (Győr, Debrecen, Kecskemét, Komárom, Miskolc) is bekapcsolódott a nemzetközi gazdasági folyamatokba.

A magyar nyelvủ plenáris ülést Józsa Viktória, a Nord Consult Kft. ügyvezetőjének előadása zárta, melyben a magyarországi regionalizmus korszakait a területi leképződés, a jogi szabályozás, a szakpolitika, a szakma és a tudomány viszonya alapján elemezte. Azt állapította meg, hogy kezdetben a megyei szintről a regionális szintre helyeződtek át a kapacitások és hangsúlyok a megfelelő intézményrendszer kiépítésével. Az elmúlt években azonban ezzel ellentétes folyamatok indultak el a regionális ügynökségek leépülésével, a megyei szerepek megerősítésével.

Ezt követően adták át a Kiváló Ifjú Regionalista Díjat. 2015-ben a Magyar Regionális Tudományos Társaság hetedik alkalommal hirdette meg a 35 évnél nem idősebb kutatóknak szóló felhívását, a díjat az MRTT tagozatvezetőkkel kibővített elnöksége Pénzes Jánosnak, a Debreceni Egyetem Társadalomföldrajzi és Területfejlesztési Tanszéke egyetemi adjunktusának ítélte oda, elismerve az elmúlt évtizedben figyelmet keltő eredményeit a hazai társadalmi térfolyamatok, a kelet-magyarországi periferikus térségek és társadalmi csoportok vizsgálata területén. Végül a fél évszázada alapított Magyar Urbanisztikai Társaság és a Magyar Regionális Tudományi Társaság együttműködési megállapodást írt alá. A két szervezet közös célja, hogy a néhány éve elindult eredményes együttmüködést az eddiginél szervezettebb, intézményesítettebb formában folytassák és új tartalmi elemekkel bővítsék.

A vándorgyülés második napjának reggelének plenáris előadását Jouke van Dijk, az Európai Regionális Tudományi Társaság (ERSA) elnöke tartotta Inequalities in human capital and regional growth in Central and Eastern Europe címmel. A Groningeni Egyetem professzora a regionális fejlődés több mutatóját vizsgálta Európában (GDP, munkanélküliség, versenyképesség stb.), amelyek nyilvánvaló különbségeket rajzolnak ki Nyugat- és Kelet-Európa között. A humán tőke területi adatokon elvégzett regressziós elemzése kimutatta, hogy Hollandiában a magasabb végzettségűek (diplomások) bizonyultak mobilabbnak, ami erősítheti a tudás- vagy agyelszívás elméleteit, azonban mégis saját térségükben maradnak legtöbben az egyetem elvégzése után. Az előadás második felében a humán tőkével kapcsolatos externáliák elemzésére került sor. A vizsgálat azt igazolta, hogy egy-egy tanulással töltött pótlólagos év 3-8 százalékkal növelheti a béreket, illetve hogy a termelési spillovereknek regionális szinten nincs kimutatható jelentősége, azonban vállalati szinten igen.

A plenáris elöadást követően tizenkét tematikus - köztük egy angol nyelvü - szekcióban folytatódott a vándorgyűlés. A szekciókban közel száz előadás hangzott el, a prezentációk letölthetők az MRTT honlapjáról: http://www.mrtt.hu. 